\title{
Pengesahan Instrumen Kesediaan Guru dan Kesediaan Teknologi Terhadap Penggunaan Telefon Pintar Dalam Kalangan Guru Reka Bentuk Teknologi Sekolah Menengah: Analisis Faktor Penerokaan (EFA)
}

\author{
Validation of Teacher Readiness and Technology Readiness Instruments on \\ Smartphone Use Among High School Technology Design Teachers: \\ Exploratory Factor Analysis (EFA)
}

\author{
Nazaruddin Abdul Hadi ${ }^{1}$, Mahizer Hamzah ${ }^{2 *}$, Norkumalasari Othman ${ }^{3}$ \\ ${ }^{1}$ Universiti Pendidikan Sultan Idris; naza9763@gmail.com \\ ${ }^{2}$ Universiti Pendidikan Sultan Idris; mahizer@fpm.upsi.edu.my \\ ${ }^{3}$ Universiti Pendidikan Sultan Idris \\ * Corresponding author
}

To cite this article (APA): Hadi, N. A., Hamzah, M., \& Othman, N. (2020). Pengesahan instrument kesediaan guru dan kesediaan teknologi terhadap penggunaan telefon pintar dalam kalangan guru reka bentuk teknologi sekolah menengah: Analisis faktor penerokaan (EFA). Journal of ICT in Education, 7(2), 27-38. https://doi.org/10.37134/jictie.vol7.2.3.2020

To link to this article: https://doi.org/10.37134/jictie.vol7.2.3.2020

\begin{abstract}
Abstrak
Kajian ini bertujuan untuk membuat semakan terhadap instrumen kesediaan guru dan kesediaan teknologi dalam kalangan guru reka bentuk teknologi (RBT) sekolah menengah memanfaatkan penggunaan telefon pintar dalam pengajaran dan pemudahcaraan $(\mathrm{PdPc})$. Seramai 125 orang guru RBT terlibat sebagai responden dalam kajian ini. Data dianalisis secara deskriptif dengan menggunakan kebolehpercayaan Alpha Cronbach dan analisis penerokaan faktor (EFA) dengan menggunakan perisian SPSS. Hasil analisis mendapati nilai Alpha Cronbach yang diperoleh adalah 0.879 dan 0.722 untuk kesediaan guru dan kesediaan teknologi masing-masing iaitu kedua-duanya adalah melebihi 0.60. Keputusan daripada EFA menunjukkan empat faktor untuk konstruk kesediaan guru dan kesediaan teknologi dengan nilai Eigen masing-masing melebihi 1.0. Konstruk kesediaan guru mempunyai nilai KMO (Kaiser-Meyer-Olkin) $0.581>0.5$ menunjukkan item-itemnya mencukupi untuk inter-korelasi dan ujian Bartlett adalah signifikan (Chi Square 3175.802, p <0.05), nilai anti-image (Measure of Sampling Adequancy - MSA) untuk korelasi item melebihi 0.5 dengan hanya satu sahaja item iaitu B12 perlu disisihkan kerana nilai yang diperoleh kurang daripada 0.50 serta nilai jumlah varians yang dijelaskan oleh empat faktor tersebut adalah 57.45 peratus. Konstruk kesediaan teknologi mempunyai nilai KMO $0.731>0.5$, ujian Bartlett adalah signifikan (Chi Square 1159.461, $\mathrm{p}<0.05$ ), nilai anti-image (Measure of Sampling Adequacy - MSA) untuk korelasi item melebihi 0.5 . Tiada item yang disisihkan dan keempat-empat faktor menyumbang sebanyak 70.12
\end{abstract}


peratus daripada varians keseluruhan. Keseluruhan dapatan menunjukkan bahawa item-item bagi instrumen kesediaan guru dan kesediaan teknologi dapat mengukur dan menjawab objektif kajian.

Kata Kunci: kesediaan guru, kesediaan teknologi, analisis faktor penerokaan (EFA).

\begin{abstract}
This study aims to review the instruments of teacher readiness and technology readiness among high school technology design (RBT) teachers utilizing the use of smartphones in teaching and facilitation $(\mathrm{PdPc})$. A total of $125 \mathrm{RBTs}$ teachers were involved as respondents in this study. The data were analyzed descriptively by access Alpha Cronbach reliability and EFA analysis using SPSS software. The results of the analysis show that Alpha Cronbach value were 0.879 and 0.722 for teacher readiness and technological readiness, respectively, which was greater than 0.60. Results from the EFA show four factors for teacher readiness and technology readiness with Eigen values above 1.0. Teacher readiness construct with a KMO value (Kaiser-Meyer-Olkin) $0.581>0.5$ showed that the items were adequate for inter-correlation and that Bartlett's test was significant (Chi Square 3175.802, $\mathrm{p}<0.05$ ), anti-image value (Measure of Sampling Adequacy - MSA) for a correlation of more than 0.5 items with only one item B12 to be excluded because the value obtained is less than 0.50 and the total variance value explained by these four factors is 57.45 percent. The technology readiness construct had a KMO value of 0.731>0.5, the Bartlett test was significant (Chi Square 1159.461, p <0.05), the anti-image value (Measure of Sampling Adequacy - MSA) for item correlation greater than 0.5. No items were excluded, and all four factors accounted for 70.12 percent of the overall variance. The overall findings indicate that items for teacher readiness and technological readiness can measure and answer the objectives of the study.
\end{abstract}

Keywords: teacher readiness, technology readiness, exploratory factor analysis (EFA).

\title{
PENGENALAN
}

Telefon pintar atau smart phones merupakan salah satu kategori peranti lebih mudah alih berbanding dengan komputer riba dan tablet yang dikategorikan sebagai peranti mudah alih (Brown \& Diaz, 2010). Peranti yang lebih mudah alih ini merujuk kepada saiz telefon pintar yang boleh dimuatkan ke dalam poket dan fleksibel. Perkembangan semasa dalam pemilikan telefon pintar ini jelas menunjukkan kepesatan teknologi baru yang tidak terkawal yang membolehkan pengguna mengakses maklumat dengan lebih pantas selain meningkatkan kualiti dalam aktiviti harian dan sebagainya.

Kewujudan peranti mudah alih mobile devices sebagai salah satu bahan bantu pengajaran dan pembelajaran (PdP) menjadi pilihan kerana kemampuannya mencetuskan motivasi murid, menggalakkan pembelajaran secara interaktif, menyediakan konteks pembelajaran yang lebih autentik dan juga dapat meningkatkan perkembangan pembelajaran dengan menggunakan aplikasi sosial seperti Telegram (Zanaton \& Sumaiyah, 2017). Justeru itu, Jabatan Pelajaran Negeri (JPN) telah bekerjasama dengan Pusat Kegiatan Guru (PKG) dan Bahagian Teknologi Pendidikan Negeri (BTPN) dalam menyediakan beberapa siri latihan dan intervensi yang mencakupi semua hierarki guru dengan objektif utama latihan adalah untuk menggalakkan dan memanfaatkan penggunaan peranti mudah alih 
Pengesahan Instrumen Kesediaan Guru dan Kesediaan Teknologi Terhadap Penggunaan Telefon Pintar dalam Kalangan Guru Reka Bentuk Sekolah Menengah: Analisis Faktor Penerokaan (EFA)

Received Date: 21 June 2020; Accepted Date: 27 June 2020; Published Date: 03 July 2020

khususnya telefon pintar dan tablet sebagai alat bahan bantu mengajar semasa dalam proses PdPc (BTP, 2016). Guru yang menghadiri latihan diberi pendedahan tentang kepelbagaian fungsi telefon pintar dan mengubah persepsi guru terhadap fungsi telefon pintar yang bukan hanya sekadar untuk mencari maklumat sahaja. Guru juga diberi pendedahan mengenai fungsi screen mirroring pada telefon pintar yang boleh disambungkan secara tanpa wayar dengan LCD dan televisyen (BTP, 2016).

Menerusi kepelbagaian fungsi telefon pintar terutamanya sebagai alat sokongan bahan bantu mengajar guru dan pembangunan aplikasi pembelajaran dalam kelas telah mendorong pihak KPM untuk meletakkan penggunaan telefon pintar sebagai salah satu inisiatif dalam program KPM untuk peringkat sekolah bagi tahun 2019 yang mana matlamat dan objektif utama program ini adalah untuk menggalakkan guru-guru menggunakan telefon pintar dan tablet dalam proses PdPc (KPM, 2018). Program terbaru peringkat sekolah tahun 2019 tersebut telah dilancarkan oleh Menteri Pendidikan dengan tujuan untuk memanfaatkan telefon pintar dalam PdPc sebagai inisiatif kelima daripada 12 inisiatif tersebut (KPM, 2018). Memanfaatkan penggunaan telefon pintar sebagai alat bahan bantu mengajar dalam PdPc guru merupakan agenda utama ke arah pembelajaran abad ke-21 (KPM, 2016b).

Peralihan kepada penggunaan telefon pintar dalam PdPc sebagai alat bahan bantuan mengajar merupakan kaedah yang terbaik untuk merapatkan jurang digital yang wujud dalam persekitaran iklim sekolah yang seharusnya perlu bergerak seiring dengan kemajuan ke arah teknologi digital (Marwan, Madar, \& Fuad, 2013). Malah, Wood (2003) turut menyatakan bahawa penggunaan telefon pintar sebagai alat teknologi tanpa wayar (wireless) dalam pendidikan dapat menyumbang ke arah menyelesaikan jurang digital dalam kalangan negara membangun berdasarkan kepada harganya yang jauh lebih murah berbanding komputer peribadi.

\section{REKA BENTUK TEKNOLOGI}

Menerusi Dokumen Standard Kurikulum dan Pentaksiran (DSKP) Reka Bentuk Teknologi (RBT) telah dinyatakan bahawa komponen subjek RBT tingkatan dua memerlukan guru mengajar menggunakan telefon pintar untuk topik Reka Bentuk Mekanikal. Manakala Standard Kandungan Reka Bentuk Elektronik pula menetapkan Standard Pembelajaran memerlukan murid boleh membuat penyambungan litar input dan litar output kepada mikro pengawal (BPK, 2016). Keseluruhan DSKP RBT tingkatan satu, dua dan tiga mencadangkan agar guru menggunakan telefon pintar bersama dengan aplikasi-aplikasi tertentu seperti magnet code dalam pengintegrasian teknologi pengautomasian robotik (BPK, 2017; BPK, 2016).

Seterusnya, Standard Kandungan Reka Bentuk Mekatronik bagi RBT tingkatan tiga telah menetapkan bahawa murid perlu membuat pengaturcaraan untuk projek Mekatronik (BPK, 2017). Tajuk Mekatronik tingkatan tiga merupakan kesinambungan tajuk Elektronik tingkatan dua. DSKP RBT tingkatan dua turut mencadangkan guru menggunakan telefon pintar sebagai alat bahan bantu mengajar untuk murid menulis pengaturcaraan mudah berdasarkan penyambungan litar input dan litar output 
(BPK, 2016). Edison, Tina pro, crocodile, tools, protius dan work bench merupakan perisian khas yang dicadangkan. Namun, selain perisian yang dicadangkan oleh BPK, terdapat juga perisian lain yang boleh digunakan oleh guru dan pihak sekolah seperti perisian magnetcode yang membolehkan guru dan murid menggunakan komputer atau telefon pintar. Sehubungan itu, didapati telefon pintar adalah lebih mudah dan fleksibel digunakan untuk membantu PdPc guru RBT.

Terdapat kajian yang lebih mengakui keberkesanan penggunaan aplikasi pengajaran menerusi telefon pintar dalam pendidikan adalah lebih mudah digunakan (Ahmad-Fkrudin \& Ammar Badruddin, 2018; Fariza, Md Yusoff \& Mohd Khalid, 2016) dan lebih mendapat perhatian dalam kalangan pengajar kerana lebih sofistikated, dinamik, saiznya yang kecil, fleksibel dan lebih mudah alih yang lebih memberi ruang untuk mendapatkan akses maklumat tidak kira bila dan di mana (Al-Barashdi, Buoazza, \& Jabur, 2015; Alfawareh \& Jusoh, 2014). Kelebihan teknologi yang ada pada telefon pintar yang mampu beroperasi seperti komputer (Hafidha, Abdelmajid \& Naeema, 2015) didapati lebih memberi banyak kemudahan kepada pengajar yang sekaligus mampu memilikinya (Lay-Yee, KokSiew, \& Chan Yin-Fah, 2013).

\section{KESEDIAAN GURU DAN KESEDIAAN TEKNOLOGI}

Kesediaan guru bermaksud kesanggupan seseorang guru memikul tanggungjawab yang meliputi aspek-aspek seperti minat, sikap, pengetahuan dan kemahiran (Wearmouth, Edward \& Richmond, 2000). Pengetahuan dan kemahiran merujuk kepada kefahaman, kecekapan dan kepintaran terhadap sesuatu perkara atau melakukan sesuatu perkara. Sikap dan minat pula merujuk kepada perkaraperkara yang berkaitan dengan semangat dan perasaan jiwa yang kental. Tiga aspek utama yang menjadi pendorong kepada kesediaan guru untuk menggunakan teknologi mudah alih dalam PdPc iaitu (i) persepsi terhadap kemudahan penggunaan teknologi mudah alih; (ii) kemahiran penggunaan teknologi mudah alih; dan (iii) sikap guru terhadap penerimaan penggunaan teknologi mudah alih (Siti Hajar Halili \& Suguneswary, 2016). Manakala, kesediaan teknologi ditakrifkan sebagai kehendak "pengguna" untuk mengadaptasikan dan menggunakan teknologi untuk mencapai objektif mereka dalam aktiviti harian dan juga perniagaan (Parasuraman \& Colby, 2015). Sewaktu dalam peringkat mengadaptasikan teknologi baharu, pengguna mula menunjukkan perasaan positif atau negatif terhadap produk teknologi melalui pendapat positif atau negatif mereka terhadap produk tersebut. Perasaan tersebut diperiksa di bawah empat aspek iaitu keyakinan, inovasi, ketidakselesaan dan ketidakyakinan. Keyakinan dan inovasi merupakan perasaan positif pengguna manakala ketidakselesaan dan ketidakyakinan merupakan perasaan negatif (Parasuraman \& Colby, 2015). Justeru itu, kesediaan guru dan kesediaan teknologi dalam konteks kajian ini digambarkan melalui penglibatan para guru memanfaatkan penggunaan telefon pintar di dalam PdPc.

Telefon pintar sangat berpotensi untuk tujuan pembelajaran sejajar dengan perkembangan semasa, di mana semua maklumat dapat disalurkan dengan cepat dan proses kolaborasi boleh berlaku secara pantas dalam talian serta perkongsian maklumat merupakan satu bentuk pendekatan pembelajaran yang bermakna (Song, Murphy \& Farley, 2013). Kapasiti telefon pintar yang mampu beroperasi 
Pengesahan Instrumen Kesediaan Guru dan Kesediaan Teknologi Terhadap Penggunaan Telefon Pintar dalam Kalangan Guru Reka Bentuk Sekolah Menengah: Analisis Faktor Penerokaan (EFA)

Received Date: 21 June 2020; Accepted Date: 27 June 2020; Published Date: 03 July 2020

seperti komputer telah memberi banyak kemudahan kepada pengguna dan diibaratkan seperti komputer mini yang mempunyai kapasiti sebuah telefon (Meenakshi Katyal, 2017; Lay-Yee, KokSiew \& Chan Yin-Fah, 2013) menjadikan pembelajaran berasaskan telefon pintar semakin berpotensi dan pesat berkembang (Song, Murphy \& Farley, 2013).

Pembelajaran akan menjadi lebih menyeronokkan jika mengintegrasikan penggunaan telefon pintar dalam aktiviti pembelajaran kerana penggunaannya sebagai sebahagian daripada alat mempermudah kan pembelajaran turut dilihat mampu menarik minat murid untuk meneroka topik yang dipelajari dengan lebih mendalam (Fariza, Md Yusoff \& Mohd Khalid, 2016). Diakui oleh kajian Normah, Nor Azhan \& Mariam (2017) yang mendapati penggunaan telefon pintar dalam PdP telah dapat menyuntik motivasi belajar murid-murid apabila guru menggunakan aplikasi WhatsApp sebagai platform pembelajaran kolaboratif yang berkonsepkan "bimbingan rakan" di antara guru dengan murid dan murid dengan murid. Di samping itu, platform tersebut telah dapat memperluaskan lagi kepelbagaian aplikasi lain dalam telefon pintar yang boleh digunakan untuk tujuan PdPc (Normah, Nor Azhan \& Mariam, 2017). Menerusi lampiran atau attachment yang menarik dan bersesuaian yang boleh dikongsi dalam aplikasi WhatsApp seperti kontak, gambar, lokasi, video dan audio, telah membantu tugas-tugas PdPc menjadi lebih mudah, menarik serta lebih difahami oleh murid-murid (Ahmad Taufiq, 2015). Namun, tidak dinafikan pelaksanaan dan penghasilannya memerlukan kesediaan guru dari aspek pengetahuan, kemahiran, minat dan sikap serta kesediaan teknologi dari aspek inovasi dan keyakinan yang positif.

Kajian oleh Norijah, Haslina dan Md. Nor Zamani (2014) mendapati kesediaan teknologi guru dari aspek penggunaan kamera digital dan peralatan audio pada telefon bimbit untuk kegunaan dalam PdP berada pada tahap sederhana. Begitu juga dengan kemahiran mencari sumber pembelajaran digital menerusi telefon bimbit turut berada pada tahap sederhana. Guru juga didapati kurang mahir untuk mereka bentuk dan menghasilkan sumber pembelajaran. Namun, guru-guru bersetuju bahawa penggunaan peranti mudah alih seperti telefon bimbit yang boleh menunjukkan imej bergambar seperti kamera video membantu untuk memudahkan kerja guru dan membantu objektif pengajaran menjadi lebih mudah difahami oleh murid-murid.

Aliff dan Mohd Isa (2013) menerusi kajian terhadap guru Pendidikan Islam yang melaksanakan mpembelajaran dengan menggunakan telefon bimbit, mendapati hanya $40.6 \%$ iaitu skor sederhana sahaja diperoleh untuk guru-guru yang berjaya dalam aktiviti merakam suara dan penghasilan video PdP manakala untuk aktiviti penyuntingan dokumen pula mendapat skor yang paling rendah iaitu 9.4\%. Dapatan ini jelas memperlihatkan bahawa aspek kesediaan guru dan juga teknologi masih rendah, ditambahkan pula terdapat segelintir guru iaitu seramai 9.4\% guru telah menolak telefon bimbit sebagai alat yang membantu PdP (Aliff \& Mohd Isa, 2013).

Berdasarkan beberapa kajian di atas telah memperlihatkan betapa pentingnya kesediaan guru dan kesediaan teknologi dalam memanfaatkan penggunaan telefon pintar dalam PdPc. Walaupun dapatan 
kajian adalah berdasarkan kepada kajian terhadap penggunaan aplikasi umum yang terdapat pada telefon pintar atau telefon bimbit dan tidak mengkhusus kepada aplikasi khusus untuk subjek RBT, namun telah membuktikan bahawa kesediaan guru dan kesediaan teknologi termasuklah dalam kalangan guru RBT masih lagi kurang sehingga boleh mempengaruhi niat tingkah laku guru RBT untuk memanfaatkan telefon pintar dalam PdPc.

\section{ANALISIS FAKTOR PENEROKAAN (EFA) BAGI KONSTRUK KESEDIAAN GURU DAN KESEDIAAN TEKNOLOGI}

EFA dilakukan untuk mengenal pasti dan menyusun sebilangan besar item-item soal selidik ke dalam komponen-komponen di bawah satu-satu konstruk tertentu sampel kajian (Chua, 2009; Tabachnick \& Fidell, 2014). Selain itu, EFA dijalankan bagi mendapatkan komponen-komponen baharu yang terbaik dari data yang diperoleh terhadap sampel kajian (Hair, Black, Babin, \& Anderson, 2014). Dalam kajian ini, EFA dilaksanakan untuk mengenal pasti komponen-komponen yang terdapat dalam konstruk terpilih yang akan digunakan dalam analisis. Proses ini memerlukan proses pengguguran item-item yang tidak berkorelasi sehingga membentuk komponen-komponen tunggal dalam satu-satu soal selidik.

Untuk analisis EFA bagi kajian rintis ini dengan saiz sampel seramai 125 orang, faktor pembeban yang ditetapkan adalah melebihi 0.5 (Hair, Black, Babin, \& Anderson, 2014). Kesesuaian data sampel menerusi ujian Kaiser-Meyer-Olkin (KMO) dengan nilai KMO 0.50 sebagai nilai minimum untuk analisis faktor yang baik (Tabachnick \& Fidell, 2014) dan ujian Keseferaan Barlett (Bartlett's Test of Sphericity) menggunakan nilai kesignifikan ( $\operatorname{sig}<0.05)$ (Yong \& Pearce, 2013). Nilai eigen ialah $\geq$ 1.0 bagi menentukan bilangan faktor yang mewakili dimensi-dimensi sesuatu konstruk yang diukur dan dianggap signifikan untuk mengekalkan bilangan faktor tersebut (Hair et al., 2014). Seterusnya, struktur faktor untuk setiap konstruk dibangunkan secara berasingan berasaskan kepada kaedah mengekstrak indikator asas analisis kompenen utama, PCA (principal component analysis) dengan teknik putaran varimax (varimax rotation technique) menggunakan Kaiser Normalization untuk meminimumkan korelasi antara faktor dan memaksimumkan korelasi dalam faktor (Nunnally, 1978). Sehubungan itu, dirumuskan bahawa langkah-langkah penganalisisan data bagi prosedur EFA hendaklah memenuhi indeks kebagusan (goodness-of-fit) seperti di Jadual 1.

Jadual 1: Indeks Kebagusan (Indeks Goodness-of-Fit) untuk Analisis Faktor Penerokaan (EFA) (Yong \& Pearce, 2013; Tabachnick \& Fidell, 2014; Hair et al., 2014)

\begin{tabular}{lc}
\hline Indeks Model EFA & Nilai yang Dicadangkan \\
\hline Ujian Keseferaan Barlett (Barlett's Test of Sphericity)/ $\chi^{2}$ (Sig. $\left.<0.05\right)$ & $<0.05$ \\
Kecukupan sampel/ Kaiser-Meyer-Olkin (KMO) & $\geq 0.50$ \\
Nilai faktor pembeban (loading factor) & $\geq 0.50$ \\
Keseragaman (communalities) & $\geq 0.30$ \\
Nilai Eigen (Eigen value) & $\geq 1.00$ \\
Peratus sumbangan varians terhadap faktor & $\geq 3.00$ \\
\hline
\end{tabular}


Pengesahan Instrumen Kesediaan Guru dan Kesediaan Teknologi Terhadap Penggunaan Telefon Pintar dalam Kalangan Guru Reka Bentuk Sekolah Menengah: Analisis Faktor Penerokaan (EFA)

Received Date: 21 June 2020; Accepted Date: 27 June 2020; Published Date: 03 July 2020

\section{OBJEKTIF}

Mengesahkan instrumen kesediaan guru dan kesediaan teknologi guru RBT sekolah menengah memanfaatkan penggunaan telefon pintar dalam PdPc.

\section{METODOLOGI}

Kajian rintis ini melibatkan seramai 125 orang guru RBT di negeri Melaka dan bilangan ini adalah sesuai untuk kajian rintis yang melibatkan analisis faktor penerokaan (EFA) (Hair et al., 2014). Kajian ini menggunakan instrumen soal selidik sedia ada yang telah diadaptasi dan diubahsuai daripada kajian lepas untuk mengukur Kesediaan Guru (Pengetahuan, Sikap, Minat dan Kemahiran) dan Kesediaan Teknologi (Keyakinan, Inovasi, Ketidakselesaan dan Ketidakyakinan). Item-item soal selidik dalam kajian Tay, Kirar \& Litat (2015) dan Parasuraman \& Colby TRI 2.0 Indeks (2015) adalah amat dirujuk bagi mendapatkan maklumat mengenai konstruk-konstruk tersebut. Soal selidik terdiri daripada dua bahagian iaitu bahagian A untuk demografi dan bahagian B terdiri daripada 46 item untuk mengukur konstruk kesediaan guru dan kesediaan teknologi seperti yang telah diperincikan di Jadual 2. Dapatan dari kajian rintis ini dianalisis dengan menggunakan Statistical Package for the Social Sciences (SPSS) versi 22.

Jadual 2: Perincian Item Mengikut Bahagian

\begin{tabular}{clc}
\hline Bahagian & Konstruk/Sub Konstruk & Bilangan Item \\
\hline A & Demografi Guru & 9 \\
B & Kesediaan Guru & 6 \\
& - Pengetahuan & 10 \\
& - Sikap & 7 \\
& Minat & 7 \\
& Kemahiran & \\
Cesediaan Teknologi & 4 \\
& - Keyakinan & 4 \\
& - Inovasi & 4 \\
& - Ketidakselesaan & 4 \\
& &
\end{tabular}

\section{PERBINCANGAN}

\section{Kebolehpercayaan Instrumen Alpha Cronbach Bagi Konstruk Kesediaan Guru dan Kesediaan Teknologi}

Kajian ini menggunakan kebolehpercayaan dalaman bagi menguji ketekalan tindak balas responden terhadap item yang diukur. Memandangkan pemilihan maklum balas (respons) instrumen adalah dalam bentuk skala interval, pekali Alpha Cronbach $(\alpha)$ digunakan bagi memperoleh indeks kebolehpercayaan dalaman instrumen (Sekaran, 2003). Menurut Louis (2018) dan Gay, Mills \& 
Airasian (2012), nilai kebolehpercayaan adalah dari 0 (tiada kebolehpercayaan dalaman) sehingga 1.0 (kebolehpercayaan dalaman yang sempurna). Meskipun tiada batasan khusus bagi menentukan pekali kebolehpercayaan yang sesuai bagi sesuatu alat kajian, nilai pekali yang lebih daripada 0.6 sering digunakan dalam kajian (Babbie, 1992; Sekaran, 2003; Mohd Majid, 2005; Creswell, 2012) seperti di Jadual 3. Untuk kajian ini, nilai pekali Cronbach Alpha $(\alpha)$ yang diguna pakai adalah 0.6 dan ke atas.

Jadual 3: Klasifikasi Indeks Kebolehpercayaan

(Babbie, 1992; Sekaran, 2003; Mohd Majid, 2005; Creswell, 2012)

\begin{tabular}{lc}
\hline Indikator & Nilai pekali Cronbach Alpha, $(\boldsymbol{\alpha})$ \\
\hline Sangat tinggi & $0.90-1.00$ \\
Tinggi & $0.70-0.89$ \\
Sederhana & $0.30-0.69$ \\
Rendah & $0.0-0.29$ \\
\hline
\end{tabular}

Jadual 4 menunjukkan nilai kebolehpercayaan pekali Alpha Cronbach $(\alpha)$ yang diperolehi bagi setiap konstruk kajian ini. Pekali $(\alpha)$ bagi sub konstruk berada dalam lingkungan julat antara 0.746 hingga 0.894 manakala konstruk kesediaan guru dan kesediaan teknologi ialah 0.879 dan 0.722 masingmasing. Dapatan ini menunjukkan bahawa instrumen soal selidik ini mempunyai tahap kebolehpercayaan yang tinggi mengikut klasifikasi Babbie (1992) kerana pekali ( $\alpha$ ) melebihi 0.6. Sehubungan ini, kesemua 46 item dikekalkan dan sangat konsisten digunakan untuk proses memungut data.

Jadual 4: Ujian Kebolehpercayaan Kaji Rintis bagi Nilai Pekali Alpha Cronbach (A)

\begin{tabular}{llccc}
\hline Konstruk & Sub-Konstruk & Bilangan Item & $\begin{array}{c}\text { Alpha Cronbach } \\
\text { Sub- Konstruk }\end{array}$ & $\begin{array}{c}\text { Alpha } \\
\text { Cronbach } \\
(\boldsymbol{\alpha})\end{array}$ \\
\hline Kesediaan Guru & Pengetahuan & 6 & .822 & .879 \\
& Sikap & 10 & .799 & .831 \\
& Minat & 7 & .800 & .722 \\
Kesediaan Teknologi & Kemahiran & 7 & .746 & .838 \\
& Keyakinan & 4 & .850 & .894 \\
\hline Jumlah Item & Inovasi & 4 & & \\
\hline
\end{tabular}

\section{Analisis Faktor Penerokaan Konstruk Kesediaan Guru}

Keputusan EFA terhadap kesediaan guru menjelaskan prosedur analisis korelasi anti imej menunjukkan nilai pekali korelasi adalah lebih daripada 0.5 dan ini memberi gambaran bahawa analisis faktor boleh diteruskan. Ukuran kecukupan pensampelan Kaiser-Meyer-Olkin (KMO) dan Bartlett's Test of Sphericity yang diperoleh menunjukkan nilai KMO ialah 0.581, manakala ujian Bartlett's Test Sphericity adalah signifikan dengan nilai Chi-Square 3175.802 pada darjah kebebasan 435 (Jadual 5). 
Jadual 5: Ujian Kesesuaian Penggunaan Analisis Faktor dan Keseragaman Item KMO dan Bartlett's Test Terhadap Konstruk Kesediaan Guru

\begin{tabular}{lll}
\hline Kaiser-Meyer-Olkin & Measure of Sampling Adequacy & $\mathbf{0 . 5 8 1}$ \\
\hline Bartlett's Test of Sphericity & Approx. Chi-Square Spherecity & 3175.802 \\
& df & 435 \\
& Sig. & .000 \\
\hline
\end{tabular}

Analisis faktor dilakukan dengan pengkaji menetapkan bilangan faktor yang bakal diekstrak kepada empat seperti yang telah dikategorikan dalam soal selidik. Jadual 6 menunjukkan matriks komponen dengan putaran varimax. Kaedah putaran varimax dilakukan kerana dapat mengurangkan jumlah konstruk yang kompleks dan dapat meningkatkan hasil jangkaan. Hasil keputusan mendapati bahawa item-item B12 telah digugurkan kerana mempunyai nilai 'anti-image correlation matrix' kurang daripada 0.5 manakala item-item lain dikekalkan dan dikelompokkan mengikut faktor-faktor yang ditetapkan seperti di Jadual 6.

Jadual 6: Matrik Komponen dengan Putaran Varimax Konstruk Kesediaan Guru

\begin{tabular}{|c|c|c|c|c|}
\hline \multirow{2}{*}{ Item } & \multicolumn{4}{|c|}{ Faktor } \\
\hline & Pengetahuan & Sikap & Minat & Kemahiran \\
\hline B1 & 0.727 & & & \\
\hline B2 & 0.872 & & & \\
\hline B3 & 0.658 & & & \\
\hline B4 & 0.764 & & & \\
\hline B5 & 0.747 & & & \\
\hline B6 & 0.795 & & & \\
\hline B7 & & 0.639 & & \\
\hline B8 & & 0.586 & & \\
\hline B9 & & 0.817 & & \\
\hline B10 & & 0.501 & & \\
\hline B11 & & 0.623 & & \\
\hline B13 & & 0.584 & & \\
\hline B14 & & 0.571 & & \\
\hline B15 & & 0.780 & & \\
\hline B16 & & 0.872 & & \\
\hline B17 & & & 0.658 & \\
\hline B18 & & & 0.714 & \\
\hline B19 & & & 0.704 & \\
\hline B20 & & & 0.827 & \\
\hline $\mathrm{B} 21$ & & & 0.706 & \\
\hline B22 & & & 0.629 & \\
\hline B23 & & & 0.656 & \\
\hline B24 & & & & 0.752 \\
\hline B25 & & & & 0.506 \\
\hline B26 & & & & 0.735 \\
\hline B27 & & & & 0.753 \\
\hline B28 & & & & 0.657 \\
\hline B29 & & & & 0.626 \\
\hline B30 & & & & 0.643 \\
\hline
\end{tabular}


Nilai yang ditunjukkan dalam Jadual 6 adalah pekali atau faktor pembebanan bagi setiap item yang cenderung kepada setiap faktor yang tertumpuk. Nilai ini menunjukkan hubungan korelasi antara item dengan faktor yang terbentuk dan ini merupakan kunci untuk memahami sifat faktor-faktor tersebut. Seterusnya, keputusan analisis faktor menunjukkan bahawa keempat-empat faktor menyumbang sebanyak 57.45 peratus daripada varians keseluruhan.

\section{Analisis Faktor Penerokaan Konstruk Kesediaan Teknologi}

Keputusan EFA terhadap kesediaan teknologi menjelaskan prosedur analisis korelasi anti imej menunjukkan nilai pekali kolerasi adalah lebih daripada 0.5 dan ini memberi gambaran bahawa analisis faktor boleh diteruskan. Ukuran kecukupan persampelan Kaiser-Meyer-Olkin (KMO) dan Bartlett's Test of Sphericity yang diperolehi menunjukkan nilai KMO ialah 0.731, manakala ujian Bartlett's Test Sphericity adalah signifikan dengan nilai Chi-Square 1159.461 pada darjah kebebasan 120 (Jadual 7).

Jadual 7: Ujian Kesesuaian Penggunaan Analisis Faktor dan Keseragaman Item KMO dan Bartlett's Test Terhadap Konstruk Kesediaan Teknologi

\begin{tabular}{lll}
\hline Kaiser-Meyer-Olkin & Measure of Sampling Adequacy & $\mathbf{0 . 7 3 1}$ \\
\hline Bartlett's Test of Sphericity & Approx. Chi-Square Spherecity & 1159.461 \\
& df & 120 \\
& Sig. & .000 \\
\hline
\end{tabular}

Analisis faktor dilakukan dengan pengkaji menetapkan bilangan faktor yang bakal diekstrak kepada empat seperti yang telah dikategorikan dalam soal selidik. Jadual 8 menunjukkan matriks komponen dengan putaran varimax kerana dapat mengurangkan jumlah konstruk yang kompleks dan dapat meningkatkan hasil jangkaan. Hasil keputusan mendapati tiada item yang digugurkan. Semua item dikekalkan dan dikelompokkan mengikut faktor-faktor yang ditetapkan seperti di Jadual 8.

Jadual 8: Matrik Komponen dengan Putaran Varimax Konstruk Kesediaan Teknologi

\begin{tabular}{lllll}
\hline \multirow{2}{*}{ Item } & \multicolumn{3}{c}{ Faktor } \\
\cline { 2 - 5 } & Keyakinan & Inovasi & Ketidakselesaan & Ketidakyakinan \\
\hline C1 & 0.903 & & & \\
C2 & 0.661 & & & \\
C3 & 0.760 & & & \\
C4 & 0.676 & 0.733 & & \\
C5 & & 0.817 & & \\
C6 & & 0.853 & & \\
C7 & & 0.846 & & \\
C8 & & & 0.842 & \\
C9 & & 0.789 & 0.663 \\
C10 & & 0.816 & 0.850 \\
C11 & & 0.731 & 0.894 \\
C12 & & & & \\
C13 & & & & \\
C14 & & & & \\
C15 & & & & \\
C16 & & & & \\
\hline
\end{tabular}


Pengesahan Instrumen Kesediaan Guru dan Kesediaan Teknologi Terhadap Penggunaan Telefon Pintar dalam Kalangan Guru Reka Bentuk Sekolah Menengah: Analisis Faktor Penerokaan (EFA)

Received Date: 21 June 2020; Accepted Date: 27 June 2020; Published Date: 03 July 2020

Nilai yang ditunjukkan dalam Jadual 8 adalah pekali atau faktor pembebanan bagi setiap item yang cenderung kepada setiap faktor yang tertumpuk. Nilai ini menunjukkan hubungan korelasi antara item dengan faktor yang terbentuk dan ini merupakan kunci untuk memahami sifat faktor-faktor tersebut. Seterusnya, keputusan analisis faktor menunjukkan bahawa keempat-empat faktor menyumbang sebanyak 70.12 peratus daripada varians keseluruhan.

\section{KESIMPULAN}

Hasil kajian ini menunjukkan bahawa instrumen soal selidik ini mempunyai tahap kebolehpercayaan nilai pekali alpha Cronbach melebihi 0.7 dan tinggi mengikut klasifikasi Babbie (1992) serta sesuai digunakan dalam kajian. Manakala analisis faktor menunjukkan konstruk kesediaan guru yang terdiri daripada empat faktor (pengetahuan, sikap, minat dan kemahiran) dan konstruk kesediaan teknologi yang juga terdiri daripada empat faktor (keyakinan, inovasi, ketidakselesaan dan ketidakyakinan) dengan setiap item mempunyai faktor pembeban yang memuaskan melebihi 0.5. Justeru itu, instrumen soal selidik ini adalah dipercayai dan sah digunakan dalam kajian akan datang untuk mengukur aspek kesediaan guru dan kesediaan teknologi dalam kalangan guru RBT sekolah menengah memanfaatkan penggunaan telefon pintar dalam PdPc dalam konteks pendidikan di Malaysia.

\section{RUJUKAN}

Ahmad-Fkrudin Mohamed Yusoff \& Ammar Badruddin Romli. (2018). Kebolehgunaan Aplikasi Mudah Alih (Mobile Apps) Bagi Kursus Sains, Teknologi Dan Kejuruteraan Dalam Islam (M-Istech) Di Politeknik Malaysia. Malaysian Online Journal of Education, 2(1), 18-28.

Ahmad Taufiq Ma'mun. (2015). Efektivitas Pembelajaran Bahasa Arab Melaui Media Social whatsApp di Program BISA (Belajar Islam \& Bahasa Arab). Tesis Sarjana, Jurusan Pendidikan Bahasa Arab, Fakultas Ilmu Tarbiyah \& Keguruan Universiti Islam Negeri Sunan Kalijaga,. (Tesis Sarjana yang tidak diterbitkan). Jurusan Pendidikan Bahasa Arab, Fakultas Ilmu Tarbiyah \& Keguruan Universiti Islam Negeri Sunan Kalijaga.

Al-Barashdi, H. S., Buoazza, A., \& Jabur, N. H. (2015). Smartphone Addiction Among University Undergraduates: A Literature Review. Journal of Scientific Research \& Reports, 4(3), 210-225.

Alfawareh, H. M., \& Jusoh, S. (2014). Smartphone Usage Among University Students: Najran University Case. International Journal of Academic Research, 6(2), 321-326.

Aliff Nawi \& Mohd Isa Hamzah. (2013). Tahap Penerimaan Penggunaan Telefon Bimbit Sebagai M-Pembelajaran dalam Pendidikan Islam. Journal of Islamic and Arabic Education, 5(1), 1-10.

Babbie, E. (1992). The Practice of Social Research. California: Wardsworth Publishing Company.

Bahagian Pembangunan Kurikulum. (2016). Dokumen Standard Kurikulum dan Pentaksiran Reka Bentuk dan Teknologi Tingkatan 2. Putrajaya: Kementerian Pendidikan Malaysia.

Bahagian Pembangunan Kurikulum. (2017). Dokumen Standard Kurikulum dan Pentaksiran Reka Bentuk dan Teknologi Tingkatan 3. Kementerian Pendidikan Malaysia.

Bahagian Teknologi Pendidikan. (2016). Pelan Strategik Pembestarian Sekolah 2016 - 2020. Kementerian Pendidikan Malaysia. Putrajaya: Kementerian Pendidikan Malaysia.

Brown, M., \& Diaz, V. (2010). Mobile learning: Context and Prospects. A Report On TheELI Focus Session. EDUCAUSE Learning Initiative.

Chua Yan Piaw. (2009). Statistik Penyelidikan Lanjutan II: Ujian Regresi, Analisis Faktor dan Analisis SEM. Buku 5. Shah Alam: McGraw Hill (Malaysia) Sdn. Bhd.

Creswell, J. W. (2012). Educational Research Planning, Conducting and Evaluating Quantitative and Qualitative Research (4th ed.). Pearson Education, Inc.

Fariza Khalid, Md Yusoff Daud, \& Mohd Khalid Mohamad Nasir. (2016). Perbandingan Penggunaan Telefon Pintar Untuk Tujuan Umum Dan Pembelajaran Dalam Kalangan Pelajar Universiti. International Conference on Education and Regional Development 2016 (ICERD 2016), 173-182.

Gay, L. R., Mills, G. E., \& Airasian, P. W. (2012). Selecting Measuring Instruments. In Educational Research : Competencies 
for Analysis and Applications.

Hafidha Suleiman Al-Barashdi, Abdelmajid Bouazza, \& Naeema H. Jabur. (2015). Smartphone Addiction Among University Undergraduates: A Literature Review. Journal of Scientific Research and Reports, 4(3), $210-225$. https://doi.org/10.9734/jsrr/2015/12245

Hair, J.F.J., Black, W.C., Babin, B.J. \& Anderson, R. E. (2014). Multivariate Data Analysis (Edisi ke-7). Edinburgh Gate: Pearson Education Limited.

Sekaran, U. (2003). Research Methods For Business A Skill-Building Approach. New York: John Wiley \& Sons.

Kementerian Pendidikan Malaysia. (2016). Laporan Tahunan 2015 Pelan Pembangunan Pendidikan Malaysia $2013-2025$. Kementerian Pendidikan Malaysia, Putrajaya. https://doi.org/10.1007/s13398-014-0173-7.2

Kementerian Pendidikan Malaysia. (2018). 12 Inisiatif Terbaru Peringkat Sekolah. Putrajaya: Kementerian Pendidikan Malaysia. Retrieved from https://www.xpresi.org/kpm-keluarkan-12-inisiatif-terbaru-peringkat-sekolah-2019/

Lay-Yee, K. L., Kok-Siew, H., \& Chan Yin-Fah, B. (2013). Factors Affecting Smartphone Purchase Decision Among Malaysia Generation Y. International Journal of Asian Social Science, 3(12), 2426-2440.

Louis Cohen, L. M. and K. M. (2018). Research Methods in Education (8th ed.). London and New York: Routledge. Retrieved from www.routledge.com/cw/cohen.

Marwan, M. E., Madar, A. R., \& Fuad, N. (2013). Jasr 3(6) 527-537.Pdf, 3(6), 527-537

Mohd Majid Konting. (2005). Kaedah Penyelidikan Pendidikan. Kuala Lumpur: Dewan Bahasa dan Pustaka.

Norijah Mohamed, Haslina Hassan, \& Md. Nor Zamani Abu Hassan. (2014). Komunikasi ICT Dalam Pengajaran Terhadap Murid-Murid Pra Sekolah : Satu Tinjauan. Jurnal Penyelidikan TEMPAWAN, 31, 171-187.

Normah Husin, Nor Azhan Norul 'Azmi, \& Mariam Mat Daud. (2017). Pembelajaran Kolaboratif Melalui Aplikasi Telefon Pintar Dalam Pembelajaran Nahu. E-Jurnal Penyelidikan Dan Inovasi, 4(1), 43-63.

Nunnally, J. C. (1978). Psychometric Theory. (2nd ed.). New York: McGraw-Hill.

Parasuraman, A., \& Colby, C. L. (2015). An Updated and Streamlined Technology Readiness Index: TRI 2.0. Journal of Service Research, 18(1), 59-74. https://doi.org/10.1177/1094670514539730.

Siti Hajar Halili, \& Suguneswary. (2016). Penerimaan Guru Terhadap Penggunaan Teknologi Maklumat Dan Komunikasi Berasaskan Model Tam Dalam Pengajaran Mata Pelajaran Bahasa Tamil. Jurnal Kurikulum \& Pengajaran Asia Pasifik, 4(2), 31-41.

Song H.S.Y. Murphy A. \& Farley H. (2013). Mobile Devices For Learning In Malaysia: Then And Now. Prosiding 30th Ascilite Conference 2013, 830-834. Retrieved from http://prezi.com/sxgcdyrtpljx/mobile-devices-for-learning-in-malaysia-thenand-now/

Tabachnick, B.G., \& Fidell, L.S. (2014). Using Multivariate Statistics (Edisi ke-7). Boston: MA Pearson.

Tay, M. G., Kirar ak Sare, \& Litat Bilung. (2015). Kesediaan Pelajar Institut Pendidikan Guru dalam Pelaksanaan Kurikulum Standard Sekolah Rendah. Jurnal Penyelidikan IPG KBL, 12, 1-18.

Wood, K. (2003). Introduction To Mobile Learning (M-Learning). Diakses dari: http://ferl.becta.org.uk?display.cfm?page=65\&catid=192resid5194\&printable=1 [12 November 2019].

Yong, A.G., \& Pearce, S. (2013). A Beginner's Guide To Factor Analysis: Focusing On Explotary Factor Analysis. Tutorials In Quantitative Methods For Psychology, 9(2), 79-94.

Wearmouth, J., Edwards, G., \& Richmond, R. (2000). Teachers' Professional Development To Support Inclusive Practices. Journal of In-Service Education, 26, 37-48.

Zanaton, H.Iksan \& Sumaiyah Mohd. Saufian. (2017). Mobile Learning: Innovation in Teaching and Learning Using Telegram. IJPTE: International Journal of Pedagogy and Teacher Education, 1(1). Retrieved from https://jurnal.uns.ac.id/ijpte/article/view/5120 